\title{
Management Methods by Development of Objects of Energy Supply Taking into Account the Combined Risks
}

\author{
Ariadna Kirillova ${ }^{1, *}$, Sergei Beliakov ${ }^{1}$ and Anna Krylova $^{1}$ \\ ${ }^{1}$ Moscow State University of Civil Engineering, 129337 Yaroslavskoe sh. 26, Moscow, Russia
}

\begin{abstract}
In the article the methods of choice of optimal administrative decisions are examined on the development of objects energy supplies of housing and communal services. That would take into account nascent risks related to investment-building activity of energy supplying enterprises. It is shown that the basic condition of housing and utilities on an energy supply is the building of objects with a subsequent production, distribution and realization of electric energy, that allows at their reproduction to provide quality and reliability of energy supply to the consumers. Also the questions of decline of risks and exposure of factors, influencing on the processes of management development of objects of energy supply in the field of housing and utilities, estimation of organizationally-economic reliability and combined risks, estimation of possibility of the use of innovative energy technologies, alternative sources of energy supply, are investigated in the article. It is fixed, that risk indexes must be appraised not only on the investment stage of building object, but also on his operating stage (after commissioning) on the basis of account of the great number of risks characterizing the combined risk.
\end{abstract}

\section{Introduction}

In the conditions of steady tendency of accumulation of physical and moral deterioration of energy supply objects, and also increase of relative losses in the electric systems and decline of techno-scientific and building potential on a background of the permanent increase of rates on electric energy for consumers, including for a population, one of major strategic tasks of the state presently is a choice of optimal administrative decisions on further development of the systems energy supplies of housing and utilities, that would take into account arising risks related to investment activity of energy supplying. At the same time, it is necessary to promote the transfer of energy system objects in innovative technologies and use modern equipment and expand scientific and technical potential. [2]

Russia has huge stocks of traditional energy resources and significant reserves for the use of alternative sources. However, it is necessary to stimulate the process of construction of energy plants that use renewable sources of energy to ensure affordable, quality

\footnotetext{
*Corresponding author: serj-bel@yandex.ru
} 
electricity to consumers, especially those that are outside of centralized energy systems. [5, 3]

Solution of problems of management of development facilities allowing to identify the impact of the cost of the investment - construction projects in the field of energy supply housing and utilities services tariffs on electricity businesses territorial entities is a timely and urgent task.

Despite the large number of studies on the implementation of the investment construction projects, a number of issues related to the analysis of emerging risks and their impact on the efficiency of investment in the development of energy supply facilities of housing and utilities services remains poorly understood and requires further study. [3]

\section{Methods and algorithm}

The analysis of existing problems and the main directions of development of energy facilities in Russia showed that:

- A large part of the country with a population of about 20 million people do not have access to centralized energy grids and these areas generally have the highest fuel and energy prices;

- Part of areas lacking energy, that is in need of importation of fuel and energy supplies;

- Russia's gas, supply only $50 \%$ of the city and about $35 \%$ of rural settlements, the rest use oil and coal, which are sources of local environmental contamination;

- In a continuous rise in prices of energy and fuel, increasing the cost of connection to the networks of centralized energy and autonomous alternative energy in Russia are developing quite intensively: consumers try to provide themselves with their own sources of electricity and heat.

Under these circumstances, one of the main goals is a fundamental renewal of basic production assets of the enterprises of energy supply on the basis of domestic and international experience in the application of innovative technologies in the construction, increasing the reliability and security of energy supply provided slowdown in electricity tariffs. Achieving this objective in the construction of energy supply facilities required:

- Replacement of obsolete technologies and equipment companies' production, transmission and distribution for innovative;

- Development of new domestic innovative technologies in all areas of energy supply companies;

- Modernization of the equipment and separate units of energy plants and networks;

- Optimize the structure of generation capacity;

-Create an effective system of holistic management of functioning and development of the Unified Energy System of the country, contributing to minimize costs and reduce electricity tariffs.

Analysis of the causes and problems of the full restoration of energy supply facilities in the housing sector has allowed to classify the identified problems and to group them is presented in Table 1. 
Table 1. Analysis of the causes of problems and the full restoration of energy supply facilities in the housing and utilities sector.

\begin{tabular}{|c|c|c|}
\hline $\begin{array}{c}\text { Management } \\
\text { domain }\end{array}$ & Causes & Problems \\
\hline $\begin{array}{l}\text { Investment } \\
\text { policy }\end{array}$ & $\begin{array}{l}\text { - Lack of law framework. } \\
\text { - Strong political influence. } \\
\text { - The lack of sequence and } \\
\text { systematics in making managerial } \\
\text { decisions. } \\
\text { - Inconsistency investment decisions } \\
\text { at the federal and regional levels. }\end{array}$ & $\begin{array}{l}\text { - Lack of funding. } \\
\text { - The absence of effective } \\
\text { mechanisms to attract private } \\
\text { investment. } \\
\text { - Lack of development and } \\
\text { implementation of innovative } \\
\text { technologies. } \\
\text { - The lack of economic interest in } \\
\text { increasing the efficiency of its } \\
\text { operations, reducing losses and costs. }\end{array}$ \\
\hline Tariff policy & $\begin{array}{l}\text { - Inefficient existing system of tariff } \\
\text { regulation. } \\
\text { - Lack of regulatory framework. } \\
\text { - Short-term regulation period } \\
\text { tariffs for the population. } \\
\text { - Politicized the process of setting } \\
\text { tariffs for electricity. }\end{array}$ & $\begin{array}{l}\text { - Sustained growth in electricity } \\
\text { tariffs by region. } \\
\text { - The deterioration of the socio - } \\
\text { economic situation at the regional } \\
\text { level. }\end{array}$ \\
\hline $\begin{array}{l}\text { Technical } \\
\text { policy }\end{array}$ & $\begin{array}{l}\text {-Lack of the system of strategic and } \\
\text { technical policy. } \\
\text {-Lack or imperfection of } \\
\text { development programs. }\end{array}$ & $\begin{array}{l}\text {-High degree of depreciation of fixed } \\
\text { assets. } \\
\text {-High accident on networks. } \\
\text {-Low level of upgrade } \\
\text { fixed assets. } \\
\text {-Low reliability } \\
\text { Infrastructure. }\end{array}$ \\
\hline $\begin{array}{l}\text { Energy } \\
\text { efficiency and } \\
\text { resource } \\
\text { efficiency } \\
\text { policy }\end{array}$ & $\begin{array}{l}\text {-Weak motivation of producers and } \\
\text { energy consumers in the use of } \\
\text { energy and it saving. }\end{array}$ & -Wasteful use of electricity. \\
\hline $\begin{array}{l}\text { Personnel } \\
\text { policy }\end{array}$ & $\begin{array}{l}\text {-The loss of prestige of working } \\
\text { professions. } \\
\text { - Frequent personnel changes. } \\
\text { - Lack of labour } \\
\text { motivation. }\end{array}$ & $\begin{array}{l}\text { - The low level of training. } \\
\text {-Low Quality of the work performed. } \\
\text {-Low level of wages. }\end{array}$ \\
\hline
\end{tabular}

The development of energy supply facilities of housing and utilities services of Russia territories depends on many factors. Questions of construction of energy plants that use alternative renewable energy sources are the most relevant for areas with decentralized energy supply systems, with a deficit of energy resources and where there are favorable natural - climatic conditions. The study of these factors showed that the interest of regional authorities and municipalities for the construction of such facilities is low, which can be explained from the point of view of the authors, the uncertainty associated with an increase in electricity prices due to the implementation in the field of alternative generation projects, the lack of teaching materials for the analysis of the profitability of investments and management of emerging risks. [6]

In assessing the profitability of investment in electricity facilities take into account the characteristics of their innovative development, attractiveness to investors and the choice of investment and construction projects in the territorial unit, as well as organizational and 
economic reliability of enterprise management mechanism, taking into account the overall risk level of attractiveness of the projects for the construction of energy supply facilities for the investors is invited to assess the according to formula ( 1) based on the model $Y(f)$.

$$
Y(f)=\sum_{n=1}^{5} K(f)_{n} \times f_{n}, \text { where } f_{n}=\sum_{j} K\left(f_{n j}\right) \times f_{n j}
$$

where $K\left(f_{n j}\right)$ - weight factor fnj in the coefficients; $K(f)_{n}$ - weight factors of the group $\mathrm{fn}$ in the coefficients determined by expert assessments.

The level of attractiveness of the project is determined by the natural and climatic and geographical factors, socio-demographic, innovation and infrastructure, price, administrative and other factors. Proposed methods of management of development of energy supply facilities consist in choosing the organizational and economic decisions between the construction projects of energy plants that use alternative energy sources, close to the consumers, and the project of building the network management objects on the basis of the proposed instruments assess the profitability of investments in the development of energy supply facilities on the basis of risks analysis.

This approach is based on the justification of the maximum level of net present value (NPV) and risk analysis (R), associated with the implementation of each project individually. [10] Making decision $\left(P_{d e c}\right)$ in this case will be based on the following economic-mathematical model of selecting the direction of development of energy supply facilities of the territorial formation:

$$
\left\{\begin{array}{c}
P_{d e c}=\max \left(N P V_{c e}, N P V_{a l}\right) \\
N P V_{c e}=f\left(x_{1}, x_{2}, x_{3}, x_{4}, x_{5}, x_{6}, x_{7}, x_{8}, x_{9}, x_{10}, x_{11}, x_{12}, e\right)> \\
N P V_{a l}=f\left(x_{13}, x_{14}, x_{15}, x_{16}, x_{17}, x_{18}, e\right)>0 \\
\left(R_{c e}, R_{a l}\right) \rightarrow \min
\end{array}\right.
$$

where $N P V_{c e}$ - net present value of the project of building the network management objects based on their connection to the central energy grid, which allows for the construction of external conditions $\left(x_{1}-x_{6}\right)$, characteristic of construction projects $\left(x_{7}\right.$ $\left.x_{9}\right)$ and construction units $\left(x_{10}-x_{12}\right): x_{1}$ - the remoteness of the construction of the main production base ; $x_{2}$ - terrain complexity; $x_{3}$-climatic conditions of the territory; $x_{4}-$ the duration of the winter period; $x_{5}$ - the nature of the surface coating; $x_{6}-$ distance to the unloading station equipment and materials; $x_{7}$ - equipment and materials costs; $x_{8}-$ length of the heating main construction; $x_{9}$ - diverse nature of transmission lines; $x_{10}-$ construction labor input; $x_{11}$ - the degree of factory assembly equipment; $x_{12}$ - kinds of used vehicles; $N P V_{a l}$ - net present value of the project of building energy plants using alternative energy sources (renewable energy), which depends on the parameters $\left(x_{13^{-}}\right.$ $\left.x_{18}\right): x_{13}$ - factory equipment cost; $x_{14}$ - the foundation costs; $x_{15}$ - connection to net; $x_{16}$ - electrical equipment and materials; $x_{17}$ - resources of communication; $x_{18}$ - labor costs; e-discount rate; $R_{c e}, R_{a l}$-risk assessment for each project.

\section{Discussion and outcomes}

The construction of new energy facilities is expected to attract investment and, consequently, increase the price (tariff) for electricity. Therefore, at the stage of the 
investment decision is necessary to determine the investment component in the tariff, and to assess the level of electricity prices for end-users based on the project cost and the current outlay of electricity production on facility object, that is built and service provided.[9] Formula (3) offered for public utilities territorial entity that reflects the indicators related to the construction and subsequent operation of the new object of energy supply - for the calculation of energy prices for housing:

$$
P_{c r i t}=\frac{A_{\text {man }}+A_{p}+A_{c i v}+A_{c o m}+\sum_{t=1}^{T}\left(a_{v} \times A_{f}\right) \times q^{-t}+L \times q^{-T}}{\sum_{t=1}^{T} x_{t} \times q^{-t}}
$$

where $P_{\text {crit }}$ - critical energy unit selling price, energy production which refers to a time $t$; $A_{\text {man }}$ - energy plant manufacturing costs; $A_{p}$ - engineering costs; $A_{c i v}$ - the cost of civil and erection works; $A_{\text {com }}$ - the cost of commissioning works; $T$ - equipment life; $a_{v}$ - payment per unit of electricity produced, depending on the volume of production; $x_{t}$ - amount of energy $(\mathrm{t}=1,2,3,4,5 \ldots) ; A_{f}$ - payments for the period of operation, not dependent on the amount of energy; $q$ - sales volume; $L$ - payment upon liquidation of equipment.

The sensitivity of the energy unit price to a change in the cost of building a new facility in the field of electricity allowed to disclose the risks associated with the implementation of the project. Risk indicators must be evaluated not only on the investment stage of construction of the object, but also its operational stage (after commissioning) by taking into account a number of risks that characterize the overall risk $(\mathrm{R})$.

The processes of construction and further operation of energy are inextricably linked to the operation of enterprises engaged in both production and transport and distribution of electricity. Therefore, the study was considered a multi-purpose nature of the activity of the enterprises of energy territorial and their interaction with the environment through performance indicators $\left(\mathrm{x}_{\mathrm{i}}\right)$, which include performance indicators, efficiency and profitability.

Accordingly, the proposed method of determining the reliability of the organizationaleconomic mechanism of management of the enterprises of energy supply modules on the basis of the definition of relative deviations $\left(\Delta_{i}\right)$ actually achieved the planned performance by the formula (4):

$$
\Delta_{i}=\left|\frac{x_{i \text { actual }}}{x_{i \text { plan }}}-1\right|
$$

where $x_{i \text { actual }}$ - the actual value of i- th performance index; $x_{i \text { plan }}$ - planned (or regulatory) value of the $i$-th index.

The average value of the relative deviation of actual achievements from the planned performance (or regulatory), defined by the formula (5) will characterize the organizational - economic reliability of management: 


$$
\overline{\Delta_{l}}=\sqrt[n]{\prod_{i=1}^{n} \Delta_{i}}
$$

The indicator is relative and varies from 0 to 1 , depending on its value, you can judge the degree of organizational - economic reliability of the multi-purpose oriented management mechanism of enterprises electricity territorial unit.

To this end, work is carried out with the participation of experts, which allowed to set the intervals for the mean relative deviation of actual performance against the planned (or regulatory).

The degree of mismatch can be taken as the criterion for inclusion the company of an area of risk according to the degree of organizational and economic reliability of mechanisms of management. In particular, if the calculated average deviation value falls within the range, characterized by:

0 - $5 \%$ - low risk area;

$6-10 \%$ - permissible (moderate) risk area;

$11-15 \%$ - high-risk area;

$16-100 \%$ - critical risk area.

Activities of enterprises in the field of public services of electricity includes uncertainties associated with the probability of occurrence of possible adverse events that give rise to production and technical, pricing, financial, investment and regulation risks are presented in Table 2.

Table 2. The set of combined risks in the sphere of management of development of energy supply facilities.

\begin{tabular}{|l|l|}
\hline $\begin{array}{l}\text { Events that have a negative impact on the organizational and } \\
\text { economic reliability of management mechanisms }\end{array}$ & The emerging risks \\
\hline $\begin{array}{l}\text { - Lack of experience in implementation of investment } \\
\text { projects }\end{array}$ & investment \\
\hline $\begin{array}{l}\text { - equipment failure; } \\
\text { - overload electrical network equipment; } \\
\text { - disruptions in fuel supply to energy plants; } \\
\text { - natural disasters and force majeure; } \\
\text { - the lack of wind, sun, etc. for renewable energy; } \\
\text { - the human factor (erroneous actions of staff); } \\
\text { - poor quality of management decisions; } \\
\text { - lack of qualified personnel }\end{array}$ & \\
\hline - prices encrese (fuel, etc.) & production and technical \\
\hline - reduction in solvency of demand & \\
\hline - changes in legislation; & \\
- industry monopoly & price \\
\hline
\end{tabular}

On the basis of the developed models, tools profitability of investment evaluation for selection of innovative projects for the construction of energy supply facilities and methodological approaches to the definition of the organizational and economic reliability of management mechanisms was developed the algorithm of the management of the development of energy supply facilities of housing and communal services area, which is shown in Figure 1.

In order to implement the proposed approach to the development of objects of small utilities generating proposes the creation of local investment companies for the development of facilities in the energy supply domain, which would carry out management 
of investment projects in construction and further exploitation of small generating facilities that use alternative energy sources that will help to solve a number of problems, which are of particular relevance to rural communities, small towns, areas remote from centralized energy supply system. Based on this is proposed organizational and economic model of management of innovative development of energy supply facilities of housing and communal services with the need to manage the construction and operation of energy plants that use alternative (renewable) energy sources, which is presented in Figure 2.

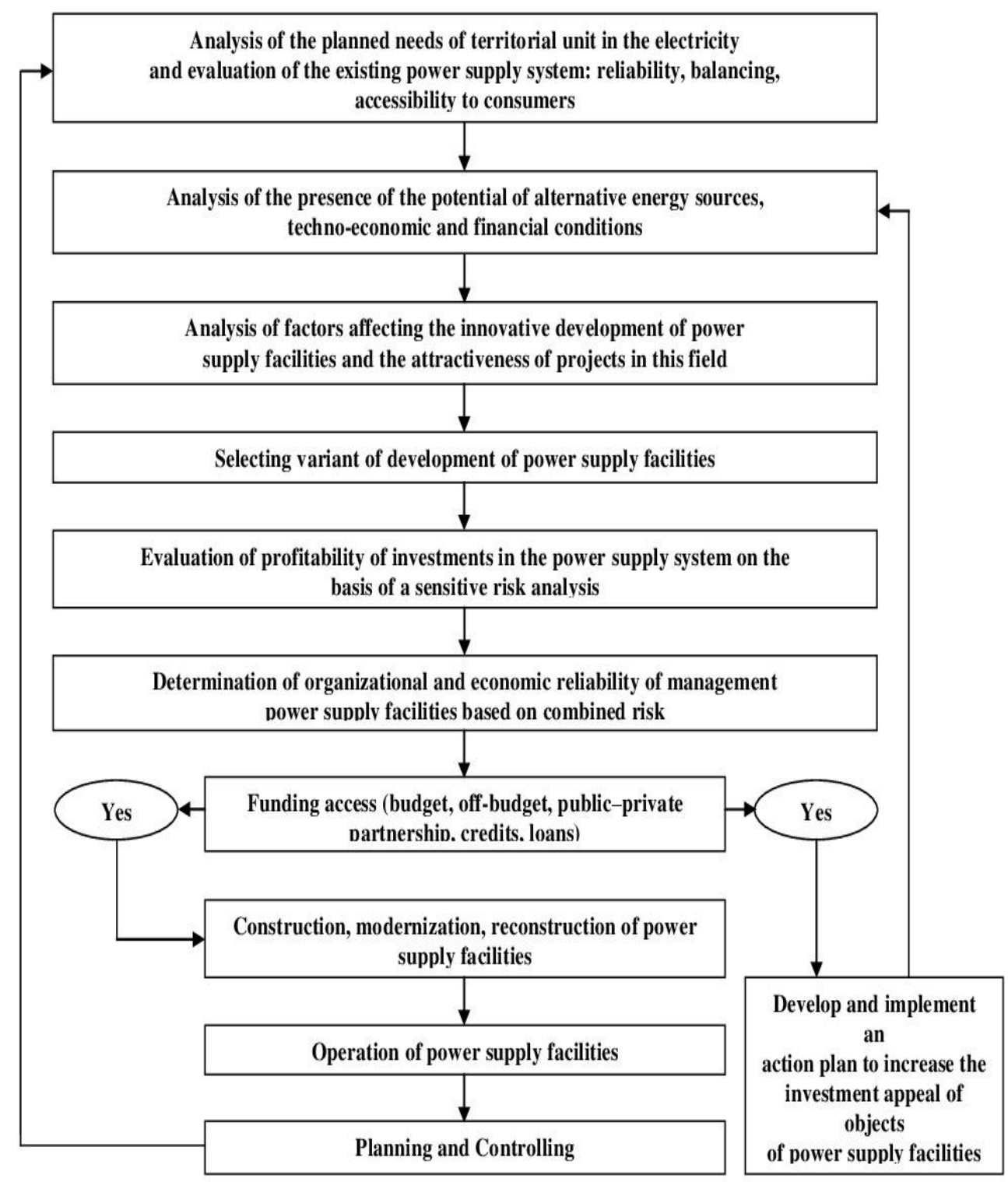

Fig. 1. Control algorithm of development of energy supply facilities housing and communal services, taking into account the combined risk. 




Fig. 2. Organizational and economic management model for innovative development of energy supply facilities of housing and communal territorial economy.

The study contains the calculation of the total cost of the project of construction of wind-energy installations (renewable resources), which amounted to 1621100 rubles, and the cost of the project to build two new transformer substations $10 / 0.4 \mathrm{kV}, 35 \mathrm{kV}$ networks and new transformer substation $35 / 10 \mathrm{kV}$ worth a total of 2700000 rubles. Hereinafter, was an examination of the risks for each of the investment projects, taking into account regional factors on the basis of the proposed thesis methodical approaches, which showed that the risks of the project of construction of wind-energy installation is much higher in many positions than for the construction project grid facilities, as shown in Table 3.

Table 3. Expert assessment of the value of total risk in the provision of public electricity services (for example, the rural settlement of Lovozero, Murmansk Region).

\begin{tabular}{|c|c|c|c|}
\hline № & $\begin{array}{c}\text { Events that have a negative impact on the } \\
\text { organizational and economic reliability }\end{array}$ & $\begin{array}{c}\text { Expert } \\
\text { assessment } \\
\text { of the risk } \\
\text { (renewable } \\
\text { resources) }\end{array}$ & $\begin{array}{c}\text { Expert } \\
\text { assessment } \\
\text { of the risk } \\
\text { for network } \\
\text { objects) }\end{array}$ \\
\hline \multicolumn{3}{|c|}{ 1. Production and technical risks } \\
\hline 1.1 & equipment malfunction & 0.25 & 0.17 \\
\hline 1.2 & $\begin{array}{c}\text { overload of electrical network equipment } \\
\text { (insufficient capacity) }\end{array}$ & 0.0 & 0.10 \\
\hline 1.3 & disruptions in fuel supply to energy plants & 0.0 & 0.24 \\
\hline 1.4 & $\begin{array}{c}\text { natural climatic events and other force } \\
\text { majeure }\end{array}$ & 0.75 & 0.12 \\
\hline 1.5 & $\begin{array}{c}\text { the lack of wind, sun, etc. for energy plants } \\
\text { using these types of energy }\end{array}$ & 0.2 & 0.0 \\
\hline
\end{tabular}




\begin{tabular}{|c|c|c|c|}
\hline 1.6 & $\begin{array}{c}\text { the human factor - the erroneous actions of } \\
\text { the operating personnel at energy and } \\
\text { dispatch management bodies }\end{array}$ & 0.17 & 0.17 \\
\hline 1.7 & poor quality of management decisions & 0.2 & 0.2 \\
\hline 1.8 & lack of qualified personnel & 0.6 & 0.3 \\
\hline \multicolumn{3}{|c|}{ 2. Price risks } \\
\hline 2.1 & prices increase (fuel, etc.) & 0.0 & 0.25 \\
\hline \multicolumn{3}{|c|}{ 3. Financial risks } \\
\hline 3.1 & slowdown of effective demand \\
\hline 4.1 & lack of experience in implementation of \\
investment projects & 0.27 \\
\hline & 5. Regulating risks \\
\hline 5.1 & legislative change & 0.6 \\
\hline 5.2 & industry monopoly & 0.2 & 0.15 \\
\hline
\end{tabular}

The cost of wind-energy installation is lower than the cost of building the network objects. However, it should be noted the high risks for wind turbines associated with climatic phenomena, the lack of experience in implementing similar projects and a lack of qualified personnel, and the risks associated with network congestion and interruptions in fuel supply, that estimated at a minimum level for the territory of the Murmansk region. Less risky for the energy supply system of rural settlement Lovozero is the construction of grid facilities. For other territorial entities need to conduct similar assessments in accordance with the proposed approach.

\section{Conclusion}

The developed tools to assess the profitability of investments and the impact of the cost of building a critical selling price of energy for consumers on the basis of risk analysis allows to take into account the impact of the cost of production of the energy plant, engineering, construction, installation and commissioning, as well as ongoing operating costs of already existing object on the rise in the cost of electricity and return on invested capital. On the basis of the proposed instruments is possible to evaluate the profitability of innovative projects relating to the construction of generation facilities that use alternative renewable

The proposed methodological approach to the evaluation of risks associated with organizational and economic reliability of management mechanism of a multi-purpose activity of the enterprises in the field of territorial energy supply is based on a set of performance indicators, efficiency and profitability.

Methodical approaches to the estimation of the overall risk associated with the uncertainty in the area of energy supply, which allows to take into account the probability of occurrence of the events that have a negative impact on the organizational and economic reliability of management mechanisms, and emerging investment, pricing, financing, regulation and production and technical risks.

\section{References}

1. P. Lombardi, T. Sokolnikova, K. Suslov, N. Voropai, Z.A. Styczynski, Renewable Energy, 90, 532-541 (2016)

2. V.A. Barinov, Analysis and forecasts, 3, 322 (2010)

3. I.A. Bashmakov, Questions of Economics, 8, 104-122 (2007) 
4. T. W. Thurner, V. Roud, Journal of Cleaner Production, 112(4), 2851-2860 (2016)

5. S.Y. Esyakov, Housing and communal services, 4, (2013)

6. E.E. Ermolaev, The economy of construction, 1(7), 24-29 (2011)

7. V. Vorotnikov, World Pumps, 3, 30-33 (2014)

8. A. Korppoo, N. Korobova, Energy Policy, 42, 213-220 (2012)

9. A.V. Svistunov, Modern economy: problems, trends, prospects, 5, 13-15 (2011)

10. A.J. Vladova, J.R. Vladov, V. Kushnarenko, N.N. Bakhtadze, IFAC Proceedings, 45(6), 929-933 (2012)

11. S. Hunt, G. Shuttleworth, Competetion and Choice in Electricity (John Wiley, Chichester, 1996)

12. Y.N. Kondrashova, O.V. Gazizova, A.V. Malapheev, Procedia Engineering, 129, 759$763(2015)$

13. T. Datsuk, G. Pozin, V. Ulyasheva, M. Kanev, Procedia Engineering, 117, 874-882 (2015)

14. T. Kossova, M. Sheluntcova International Journal of Project Management, 34(3), 403411 (2016)

15. S. Paiho, Å. Hedman, R. Abdurafikov, Ha Hoang, M. Sepponen, I. Kouhia, M. Meinander, Energy and Buildings, 66, 706-713 (2013) 